\title{
Growth, Yield and Yield Components Response of Local Sorghum Varieties to Nitrogenous Fertilizer Rates in Northern Ghana
}

\author{
Joseph Xorse Kugbe ${ }^{1 *}$, Ayamba Michael Mbawuni ${ }^{2}$ and Agyiri Wisdom ${ }^{3}$ \\ ${ }^{1}$ Department of Agronomy, University for Development Studies, Tamale, Ghana/Division of Ecology and Natural Resources Management, Center for Development, \\ University of Bonn, Bonn, Germany
}

${ }^{2}$ Department of Agronomy, University for Development Studies, Box TL 1882, Tamale, Ghana

${ }^{3}$ Department of Agronomy, University for Development Studies, Box TL 1882, Tamale, Ghana

\begin{abstract}
*Corresponding author: Joseph Xorse Kugbe, Department of Agronomy, University for Development Studies, Box TL 1882, Tamale, Ghana/ Division of Ecology and Natural Resources Management, Center for Development, University of Bonn, Walter Flex Str. 3, D53113, Bonn, Germany.
\end{abstract}

Received Date: November 18, 2019

Published Date: November 22, 2019

\section{Abstract}

In the resource-constrained, rain-fed farming communities of northern Ghana, sorghum (sorghum bicolor L. Moench) remains an important cereal crop for food security. Yield of sorghum, however, remains below $700 \mathrm{~kg} / \mathrm{ha}$ due to lack of knowledge on relative performance of local varieties under different fertilization regimes. To help improve upon the yield of the crop, field experiments were conducted at Vea in the Upper East region during the 2014 and 2017 cropping seasons to assess the effect of $\mathrm{N}$ fertilizer rates on growth and yield of local varieties to determine the best local sorghum variety that respond effectively to the most economical $\mathrm{N}$ fertilizer rates. The treatments comprised factorial combination of six nitrogen rates (0, 30, 60, 90, 120 and $150 \mathrm{~kg} \mathrm{~N} / \mathrm{ha}$ ) and three local sorghum varieties (Bawku red, Kamolg and Kadaga) tested in a Randomized Complete Block Design with four replicates. Data were collected on growth, yield and yield components of the crop and analyzed using two-way analyses of variance procedure, where means were separated at probability of 5\%. From the results, there were no significant interaction effect ( $p>0.05$ ) of $\mathrm{N}$ rates and sorghum varieties on most parameters studied. However, there were significant effect $(\mathrm{p}<0.05)$ of $\mathrm{N}$ rates on plant height, leaf number, aboveground biomass, panicle length, number of branches, number of florets, number of seeds, 200 hundred seed weight and total weight of panicle; each increasing with increasing N rate with optimum occurring at $90 \mathrm{~kg} / \mathrm{ha} \mathrm{N}$. Significantly higher grain yield was obtained in response to the application of 60 and $90 \mathrm{~kg} / \mathrm{ha} \mathrm{N}$ for the Kalmolga variety in comparison with other varieties and N-rate combinations. As Kamolga variety accrued the highest yield (1270 kg/ha) at N rate of $90 \mathrm{~kg} / \mathrm{ha}$, this combination is recommended to the resource-poor, sorghum farmers of northern Ghana.

Keywords: Sorghum varieties growth; Nitrogen fertilizer rates; Yield and yield components

List of Acronyms: ANOVA -Analysis of Variance; CV - Coefficients of Variation; WAP - Weeks After Planting; N - Nitrogen; LSD - Least Significant Difference; kg - Kilogram; MG - Milligram; t/ha - Ton per hectare; T - Treatment; FWOB - Fresh Weight of Biomass; DWOB - Dry weight of Biomass; G - Gram; HA-1 - Per Hectare; Kg/ha - Kilogram per hectare; WRC - Water Resource Commission; WASCAL - West Africa Science Center on Climate Change and Adapted Land Use; DAE - Days after Emergence; \% - Percentage

\section{Introduction}

The economic importance of Sorghum (sorghum bicolor L. Moench) to rural households and household food security in northern Ghana, remains a key reason for the continues cultivation of the crop, though average yield (700 kg/ha) is below that of maize and rice. The low yield, however, implies that sorghum could contribute more to food supplies than at present, especially in resource-constrained regions and people in greatest need. The crop has been referred to as one with vast untapped potential $[1,2]$.

Across northern Ghana the crop is preferred by farmers because of the relatively dry agricultural environment. Sorghum is an extremely drought tolerant crop and has an ability to survive and yield grain during continuous or intermittent drought stress [3]. As a result, the crop has been and is still an important staple in most Semi-Arid Tropics (SAT) of Asia and Africa [4]. In Africa, sorghum has wider geographical adaptation than any other cereal growing from lowlands to highlands [5].

Though adapted to the arid climates of northern Ghana, productivity is by far below its potential. In areas where sorghum is commonly grown, yields of more than 3000 to $4000 \mathrm{~kg} \mathrm{ha}^{-1}$ are obtained under better conditions, dropping down to 300 to $1000 \mathrm{~kg}$ 
ha $^{-1}$ as moisture, soil fertility and other biotic and abiotic factors become limiting [6].

In northern Ghana, sorghum is cultivated principally by smallholder, resource-poor farmers under rain-fed conditions. Mostly, fertilizers are not available for purchases. In some cases where fertilizers are available the farmers have no means to purchase them or lack access to fertilizer through lack of transportation to cart fertilizers to the field. Judicious use of fertilizers is paramount to sorghum production.

Despite being one of the most important staple food for many livelihoods and its adaptation to draught, research results reveal that yield levels achieved by small-scale farmers remained stagnant despite farmer's effort to improve and increase production. Across northern Ghana, poor soils and lack of knowledge on fertilizer application rates remain key factors to the reduced yield. Though a number of local varieties have been introduced to increase the yield of the crop, knowledge on best performing sorghum variety is also limited.

In order to increase sorghum production, there is a need therefore to evaluate the effect of $\mathrm{N}$ fertilizer rates on local sorghum varieties to determine the optimum $\mathrm{N}$ rate and variety. Appropriate $\mathrm{N}$ fertilization rates have been noted to increase sorghum yields. Olugbemi et al. [7], observed that application of $\mathrm{N}$ up to $150 \mathrm{~kg} / \mathrm{ha}$ increased grain number, grain yield, and harvest index. It has also been observed by Melaku et al. (2018), that sorghum varieties has responded differently to $\mathrm{N}$ application rates and that sweet sorghum varieties gives higher grain yield, biomass, plant height, leaf number and quality stalks due to its ability to respond effectively to increasing $\mathrm{N}$ application rates. In 2018 an evaluation research was conducted by Al-salim et al. [8] on local sorghum (keafer, Al-khyaer,Rabeh and Enqadh) genotypes to evaluate their response to nitrogen fertilizer application rates and it was established that the local sorghum genotypes respond well to nitrogen fertilizer rates. Sorghum genotypes have been reported to be good efficient responders or users of $\mathrm{N}$ fertilizer levels $[9,10]$. Across northern Ghana, however, knowledge on varietal response to $\mathrm{N}$ fertilization is limited. Necessitating the need for a research to develop knowledge to help improve the crops production. This research was aimed to assess the effect of $\mathrm{N}$ fertilizer rates on growth, yield and yield parameters of local sorghum varieties in northern Ghana with the objective to help identify the best local sorghum variety that responds effectively to the most economic $\mathrm{N}$ fertilizer rate for resource-poor farmers of northern Ghana.

\section{Materials and Methods}

\section{Description of the study area}

The experiment was conducted at Vea during the 2014 and the 2017 cropping seasons.

The area lies within the interior Guinea Savannah agro-ecological zone of Ghana, located in the Bolgatanga municipality of the upper east region between latitude $90 " 25 \mathrm{~N}$, longitude $00 " 58 \mathrm{~W}$.
The climatic condition of the area is warm, semiarid with an annual average rainfall of $1200 \mathrm{~mm}$ between May and September, followed by a dry windy season (harmattan) from September to April. Temperature distribution is moderately uniform with mean monthly minimum value of $31^{\circ} \mathrm{C}$ and maximum of $38{ }^{\circ} \mathrm{C}$ [11]. The relative humidity varies greatly during the wet season with monthly minimum of $25 \%$ and maximum value of $50 \%$ during the wet season [12]. The soil types include Lixisols, and Ferric Lixisols [13].

\section{Description of materials used for the study}

Local sorghum varieties called Bawku Red (BR), Kamolga (KM) and Kadaga (KA) were used for the study. Chemically treated seeds of the three varieties produced by a local seed company were used. The seeds had germination percentage of 90 - 100, pure seed percentage of 99 and moisture percentage of 12.2 .

\section{Treatments and experimental design}

A 3 by 6 factorial experiment laid out in a randomized complete block design was used for the study. The factors consisted of 3 local sorghum varieties (Bawku Red (BR), Kamolga (KM) and Kadaga (KA) and 6 nitrogenous fertilizer levels ( $0 \mathrm{~kg} / \mathrm{ha}, 30 \mathrm{~kg} / \mathrm{ha}, 60 \mathrm{~kg} /$ ha, $90 \mathrm{~kg} / \mathrm{ha}, 120 \mathrm{~kg} / \mathrm{ha}$ and $150 \mathrm{~kg} / \mathrm{ha}$ ). In all, 18 treatments were used for the study as indicated below.

T1 control $=\mathrm{BR}+$ No Fertilizer, $\mathrm{T} 2=\mathrm{BR}+\mathrm{N}-\mathrm{P}_{2} \mathrm{O}_{5}-\mathrm{K}_{2} \mathrm{O}: 30-50-50$, $\mathrm{T} 3=\mathrm{BR}+\mathrm{N}-\mathrm{P}_{2} \mathrm{O}_{5}-$

$\mathrm{K}_{2} \mathrm{O}: 60-50-50, \mathrm{~T} 4=\mathrm{BR}+\mathrm{N}-\mathrm{P}_{2} \mathrm{O}_{5}-\mathrm{K}_{2} \mathrm{O}: 90-50-50, \mathrm{~T} 5=\mathrm{BR}$ $+\mathrm{N}-\mathrm{P}_{2} \mathrm{O}_{5}-\mathrm{K}_{2} \mathrm{O}: 120-50-50, \mathrm{~T} 6=\mathrm{BR}+\mathrm{N}-\mathrm{P}_{2} \mathrm{O}_{5}-\mathrm{K}_{2} \mathrm{O}: 150-50-50$, T7 control $=\mathrm{KM}+$ No Fertilizer, $\mathrm{T} 8=\mathrm{KM}+\mathrm{N}-\mathrm{P}_{2} \mathrm{O}_{5}-\mathrm{K}_{2} \mathrm{O}: 30-50-50, \mathrm{~T} 9=\mathrm{KM}+$ $\mathrm{N}-\mathrm{P}_{2} \mathrm{O}_{5}-\mathrm{K}_{2} \mathrm{O}: 60-50-50, \mathrm{~T} 10=\mathrm{KM}+\mathrm{N}-\mathrm{P}_{2} \mathrm{O}_{5}-\mathrm{K}_{2} \mathrm{O}: 90-50-50, \mathrm{~T} 11=\mathrm{KM}$ $+\mathrm{N}-\mathrm{P}_{2} \mathrm{O}_{5}-$

$\mathrm{K}_{2} \mathrm{O}: 120-50-50, \mathrm{~T} 12=\mathrm{KM}+\mathrm{N}-\mathrm{P}_{2} \mathrm{O}_{5}-\mathrm{K}_{2} \mathrm{O}: 150-50-50, \mathrm{~T} 13$ control $=\mathrm{KA}+$ No Fertilizer, $\mathrm{T} 14=$

$\mathrm{KA}+\mathrm{N}-\mathrm{P}_{2} \mathrm{O}_{5}-\mathrm{K}_{2} \mathrm{O}: 30-50-50, \mathrm{~T} 15=\mathrm{KA}+\mathrm{N}-\mathrm{P}_{2} \mathrm{O}_{5}-\mathrm{K}_{2} \mathrm{O}: 60-50-50$, $\mathrm{T} 16=\mathrm{KA}+\mathrm{N}-\mathrm{P}_{2} \mathrm{O}_{5}-\mathrm{K}_{2} \mathrm{O}: 90-$

50-50, T17 = KA + N-P ${ }_{2} \mathrm{O}_{5}-\mathrm{K}_{2} \mathrm{O}: 120-50-50, \mathrm{~T} 18=\mathrm{KA}+\mathrm{N}-\mathrm{P}_{2} \mathrm{O}_{5}-$ $\mathrm{K}_{2} \mathrm{O}: 150-50-50$.

Four replications were used. The field had 72 experimental units each measuring $5 \mathrm{~m} \times 10 \mathrm{~m}$. The blocks (reps) were separated by a $1 \mathrm{~m}$ wide space and each plot was separated by $0.50 \mathrm{~m}$ space. Each treatment was randomly assigned to the experimental unit within a block. The gross plot size was $50 \mathrm{~m}^{2}(5 \mathrm{~m} \times 10 \mathrm{~m})$.

Ploughing was done using bullocks. The field was laid out by the use of garden lines, tape measure and pegs. Inter and intra row spacing of $50 \times 50 \mathrm{~cm}$ was used and the sorghum seeds were sown between the $15^{\text {th }}$ and $20^{\text {th }}$ of June. About four to six seeds were sown per hill and later on, seedlings were thinned to two plants per hill. Half of the $\mathrm{N}$ application rates $\left(30 \mathrm{~kg} \mathrm{ha}^{-1}, 60 \mathrm{~kg} \mathrm{ha}^{-1}, 90 \mathrm{~kg} \mathrm{ha}^{-1}\right.$, $120 \mathrm{kgha}^{-1}$ and $150 \mathrm{~kg} \mathrm{ha}^{-1}$ ) of N.P.K. 25-10-10 fertilize was used for basal application on 10 days after emergence (DAE) at $1.5 \mathrm{~g}, 2.5$ $\mathrm{g}, 4 \mathrm{~g}, 5 \mathrm{~g}$ and $6.5 \mathrm{~g}$ per stand/hill respectively. The remaining half 
of $\mathrm{N}$ application rates was applied at 30 days after the first application as top-dressing. Hand hoeing was done once at 2 weeks after sowing the sorghum and post emergence weedicides were used 3 weeks after the hand hoeing.

\section{Data collection and analyses}

\section{Growth parameters:}

- Variety name: Varieties of local sorghum used for the field experiment were named and recorded.

- $\quad$ Fresh weight of biomass (FWOB): Data recording started a month after emergence and was taken every two weeks.

- $\quad$ Dry weight of biomass (DWOB): Data recording started a month after emergence and was taken every two weeks interval.

- $\quad$ Leaf number: This was recorded a week after emergence and continued every two weeks till the flag leaf stage. This was determined by counting. Five plants that were sampled randomly and tag from the middle rows of each plot were used for this purpose.

- Plant height (cm): Plant height of sorghum was measured every two weeks from a week after emergence in centimeters. It was measured as the distances from ground level to the growth point where the panicle starts to branch. Five plants were sampled randomly from each plot in the middle rows and used for this purpose. The mean was recorded as plant height.

\section{Yield and yield components}

- $\quad$ Final total biomass (above ground biomass): This was recorded at the time when the sorghum plants were fully matured and ready for harvest. The plants were cut from the net rows and weighed from each net plot. The weighed biomass was then converted to $\mathrm{kg} / \mathrm{ha}$.

- Panicle weight: This was determined by randomly selecting five panicles and weighing the panicle with grain attached. Panicle weight was then recorded by dividing the total weight by the number of panicles.

- $\quad$ Panicle length and width: This was determined by selecting five panicles and measuring the panicle length and width of the panicle with grain attached.

- Number of spikelet's and florets: This was determined by selecting five panicles and counting the number of spikelet's and florets in the panicle.

- Two hundred seeds weight: This was determined by selecting five panicles randomly. Two hundred (200) seeds from these panicles were carefully counted after which the weight of the 200 seeds was recorded.

- Grain Yield: Grain yield was measured by weighing the grain that was threshed from the panicles obtained from the harvest area within each plot and expressed into $\mathrm{kg} / \mathrm{ha}$.

\section{Data analysis}

The data collected were subjected to analysis of variance (ANOVA) using the GenStat statistical software. The differences between treatment means were compared using Least Significant Difference (LSD) test at $5 \%$ level of significance.

\section{Results}

\section{Soil analysis}

The analysis of soil samples from the experimental field showed a maximum and minimum $\mathrm{N}$-contents of $764 \mathrm{mg} / \mathrm{kg}$ and $732 \mathrm{mg} /$ $\mathrm{kg}$ respectively (Table 1). A mean $\mathrm{N}$-content of $745 \mathrm{mg} / \mathrm{kg}$ was observed, indicating a relatively low $\mathrm{N}$-content of soils of the study area.

Table 1: Soil N-content $(\mathrm{mg} / \mathrm{kg})$ before planting of sorghum at Vea in the Upper East region of Ghana.

\begin{tabular}{|c|c|}
\hline PLOTS & N-Content \\
\hline REP 1 & 732.67 \\
\hline REP 2 & 764.67 \\
\hline REP 3 & 732.67 \\
\hline REP 4 & 750 \\
\hline Mean & 745 \\
\hline SD & 13.4 \\
\hline
\end{tabular}

\section{Plant height}

The effect of fertilizer on plant height was highly significant $(p<$ 0.001 ) at eight (8) weeks after planting (WAP). It was however not significant $(p>0.05)$ at 2, 4, 6 and 10 WAP. The effect of variety and interaction of the two factors on plant height were also not significant $(p>0.05)$ at $2,4,6,8$ and 10

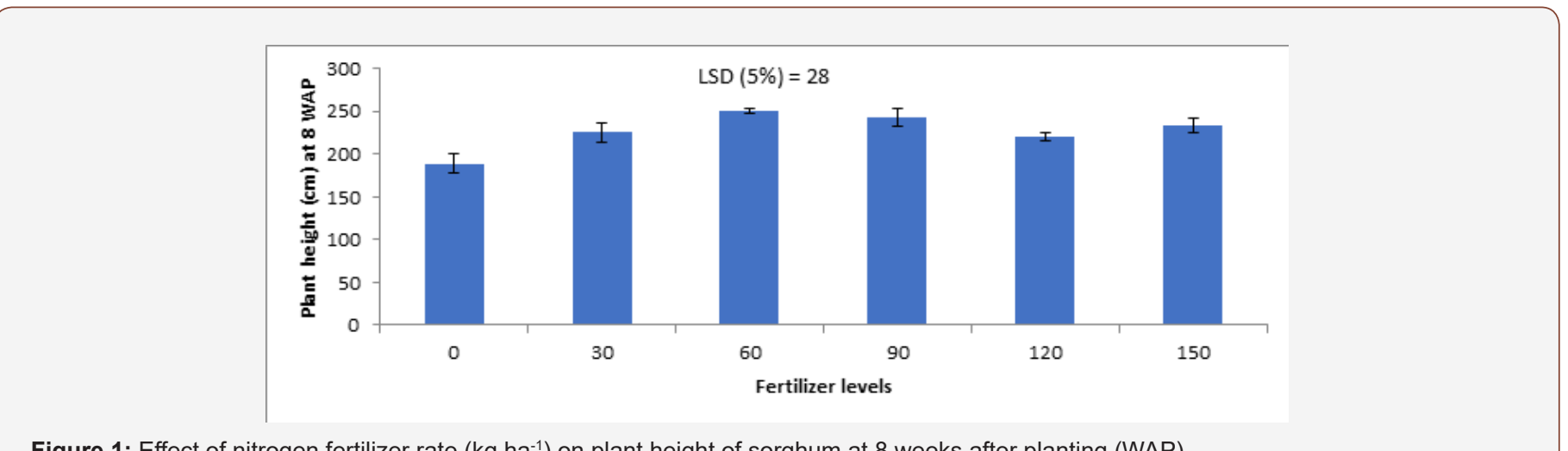

Figure 1: Effect of nitrogen fertilizer rate $\left(\mathrm{kg} \mathrm{ha}^{-1}\right)$ on plant height of sorghum at 8 weeks after planting (WAP). 
Plants fertilized with $60 \mathrm{~kg} \mathrm{~N}^{-1}$ had the highest mean height at 8 WAP (Figure 1). The plants treated with 30,90 and $150 \mathrm{~kg} \mathrm{~N}$ $\mathrm{ha}^{-1}$ had similar performance with those treated with $60 \mathrm{~kg} \mathrm{~N} \mathrm{ha}^{-1}$. The control-treated plants had the least mean height.

\section{Number of leaves}

Fertilizer rate had significant $(p<0.05)$ effect on leaf number at 4, 6, 8 and 10 WAP. Effect of fertilizer was, however, not signif- icant $(p>0.05)$ at 2 WAP. The effects of variety and interaction of the two factors on number of leaves were also not significant $(p>$ 0.05 ) at 2, 4, 6, 8 and 10 WAP. Plants fertilized with $90 \mathrm{~kg} \mathrm{~N} \mathrm{ha}^{-1}$ had the highest mean number of leaves at 8 WAP (Figure 2). The plants treated with $30,60,120$ and $150 \mathrm{~kg} \mathrm{~N} \mathrm{ha}^{-1}$ had similar performance with those treated with $90 \mathrm{~kg} \mathrm{~N}^{-1}$ especially at 8 and 10 WAP. The control-treated plants consistently had the least mean number of leaves at 4, 6, 8 and 10 WAP.

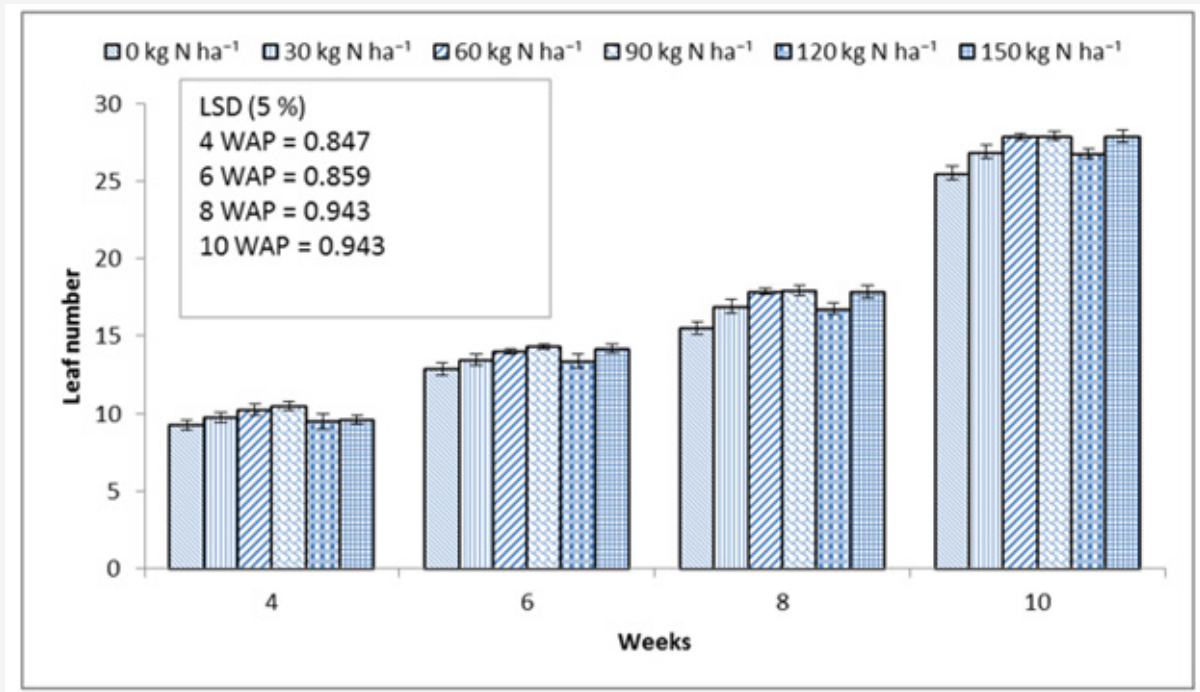

Figure 2: Effect of nitrogen fertilizer rate $\left(\mathrm{kg} \mathrm{ha}^{-1}\right)$ on number of sorghum leaves at 4, 6, 8 and 10 WAP.

\section{Biomass}

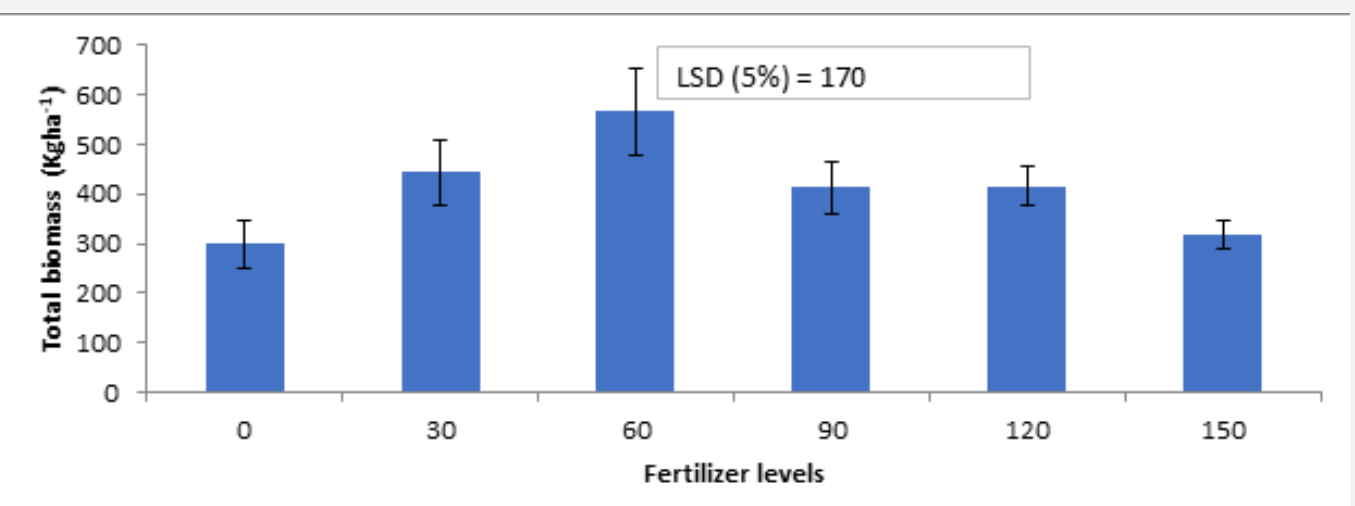

Figure 3: Effect of nitrogen fertilizer rate $\left(\mathrm{kg} \mathrm{ha}^{-1}\right)$ on the total fresh biomass of sorghum at 4 WAP.

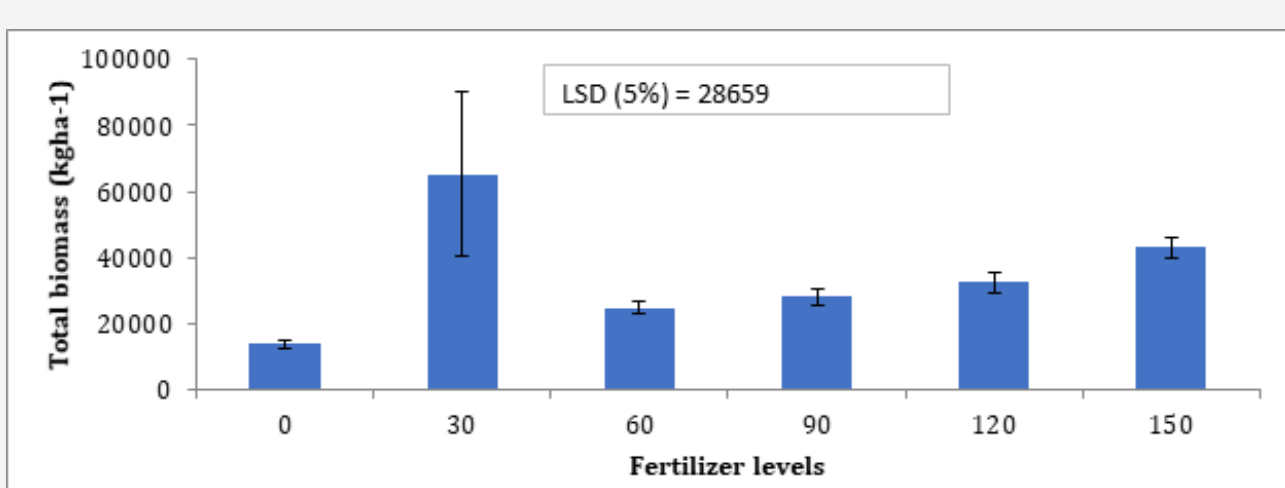

Figure 4: Effect of fertilizer $\left(\mathrm{kg} \mathrm{ha}^{-1}\right)$ on the total fresh biomass of sorghum at harvest. 
The effect of fertilizer on total biomass was highly significant $(p$ $<0.05$ ) at 4 WAP and at harvest. It was however not significant ( $p>$ $0.05)$ at 2, 6, 8 and 10 WAP. The effects of variety and interaction of the two factors on total biomass were also not significant $(p>0.05)$ at 2, 4, 6, 8 and 10 WAP. It was observed that plants fertilized at 60 $\mathrm{kg} \mathrm{N} \mathrm{ha}^{-1}$ had the highest total biomass at 4 WAP (Figure 3). The plants treated with $30,90,120$ and $150 \mathrm{~kg} \mathrm{~N}^{-1}$ had similar performance. The control-treated plants had the least total biomass. The trend was different at harvest when plants fertilized at $30 \mathrm{~kg}$
$\mathrm{N} \mathrm{ha}^{-1}$ had the highest total biomass and their performance was similar only to those treated with $150 \mathrm{~kg} \mathrm{~N} \mathrm{ha}^{-1}$ (Figure 4).

The effect of variety on sub-sample fresh biomass was significant $(p<0.05)$ at 10 WAP. It was however not significant $(p>0.05)$ at 2, 4, 6 and 8 WAP as well as at harvest. The effects of fertilizer and interaction of the two factors on sub-sample fresh biomass were also not significant $(p>0.05)$ at 2, 4, 6, 8 and 10 WAP as well as at harvest.
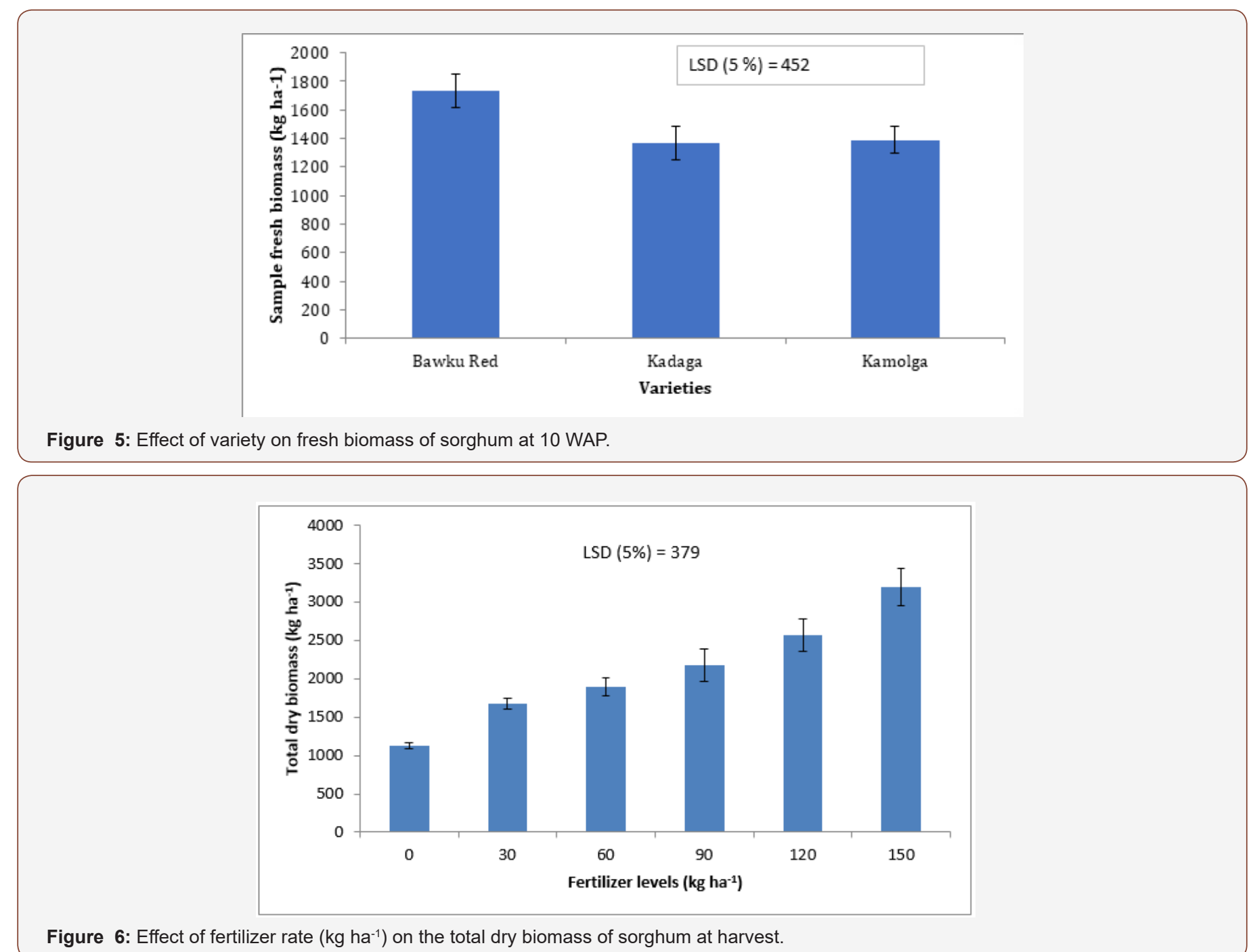

The Bawku Red variety had the highest mean fresh biomass at 10 WAP (Figure 5). The Kadaga variety had the least mean fresh biomass at 10 WAP though the Kamolga variety also performed similarly.

The effect of fertilizer rate on total dry biomass was significant $(p<0.05)$ at harvest. It was however not significant $(p>0.05)$ at 2 , $4,6,8$ and 10 WAP. The effects of variety and interaction of the two factors on total biomass were also not significant $(p>0.05)$ at 2,4 , 6, 8 and 10 WAP as well as at harvest. Plants fertilized at $150 \mathrm{~kg} \mathrm{~N}$ $\mathrm{ha}^{-1}$ had the highest total biomass at harvest (Figure 6). Total dry biomass decreased with decreasing rate of $\mathrm{N}$ application. The negative control-treated plants had the least total dry biomass.

\section{Panicle length}

Fertilizer rate significantly impacted on panicle length $(p<$ 0.05). The interaction effect of the two factors on panicle length was also significant $(p<0.05)$. Plants treated with Bawku Red x $120 \mathrm{~kg}$ $\mathrm{N}^{-1}$ had the highest mean panicle length (Table 2). Their performance was similar to that of Bawku Red combined with 0, 30, 60 and $150 \mathrm{~kg} \mathrm{~N} \mathrm{ha}^{-1}$. The Kadaga $\mathrm{x} 0 \mathrm{~kg} \mathrm{~N} \mathrm{ha}^{-1}$ treated plants had the least mean panicle length.

\section{Panicle width}

The effects of variety and fertilizer as sole factors did not significantly affect panicle width $(p>0.05)$. The interaction effect of the two factors, however, affected panicle width $(p<0.05)$. The 
Bawku red variety planted at an $\mathrm{N}$ rate of $90 \mathrm{~kg} \mathrm{ha}^{-1}$ had the widest width of $9.95 \mathrm{~cm}$ while the Kamolga variety planted at an $\mathrm{N}$ rate of

Table 2: Effect of variety and fertilizer rate on panicle length of sorghum.

\begin{tabular}{|c|c|c|}
\hline Variety & Fertilizer Level & Panicle Length $(\mathrm{cm})$ \\
\hline \multirow{6}{*}{ Bawku Red } & $0 \mathrm{~kg} \mathrm{~N} \mathrm{ha}^{-1}$ & 31.15 \\
\hline & $30 \mathrm{~kg} \mathrm{~N} \mathrm{ha}^{-1}$ & 33.05 \\
\hline & $60 \mathrm{~kg} \mathrm{~N} \mathrm{ha}^{-1}$ & 31.45 \\
\hline & $90 \mathrm{~kg} \mathrm{~N} \mathrm{ha}^{-1}$ & 28.5 \\
\hline & $120 \mathrm{~kg} \mathrm{~N} \mathrm{ha}^{-1}$ & 33.95 \\
\hline & $150 \mathrm{~kg} \mathrm{~N} \mathrm{ha}^{-1}$ & 32.4 \\
\hline \multirow{6}{*}{ Kadaga } & $0 \mathrm{~kg} \mathrm{~N} \mathrm{ha}^{-1}$ & 21.95 \\
\hline & $30 \mathrm{~kg} \mathrm{~N}$ ha $^{-1}$ & 23.3 \\
\hline & $60 \mathrm{~kg} \mathrm{~N}$ ha $^{-1}$ & 23.3 \\
\hline & $90 \mathrm{~kg} \mathrm{~N} \mathrm{ha}^{-1}$ & 26.2 \\
\hline & $120 \mathrm{~kg} \mathrm{~N} \mathrm{ha}^{-1}$ & 22.95 \\
\hline & $150 \mathrm{~kg} \mathrm{~N} \mathrm{ha}^{-1}$ & 24.95 \\
\hline \multirow{6}{*}{ Kamolga } & $0 \mathrm{~kg} \mathrm{~N} \mathrm{ha}^{-1}$ & 24.5 \\
\hline & $30 \mathrm{~kg} \mathrm{~N} \mathrm{ha}^{-1}$ & 25.75 \\
\hline & $60 \mathrm{~kg} \mathrm{~N}$ ha $^{-1}$ & 25.4 \\
\hline & $90 \mathrm{~kg} \mathrm{~N} \mathrm{ha}^{-1}$ & 25.9 \\
\hline & $120 \mathrm{~kg} \mathrm{~N} \mathrm{ha}^{-1}$ & 24.2 \\
\hline & $150 \mathrm{~kg} \mathrm{~N} \mathrm{ha}^{-1}$ & 27.85 \\
\hline LSD (5 \%) & & 2.522 \\
\hline$\% \mathrm{CV}$ & & 6.6 \\
\hline
\end{tabular}

$120 \mathrm{~kg} \mathrm{ha}^{-1}$ had the least width of $7 \mathrm{~cm}$.

\section{Total weight of panicles}

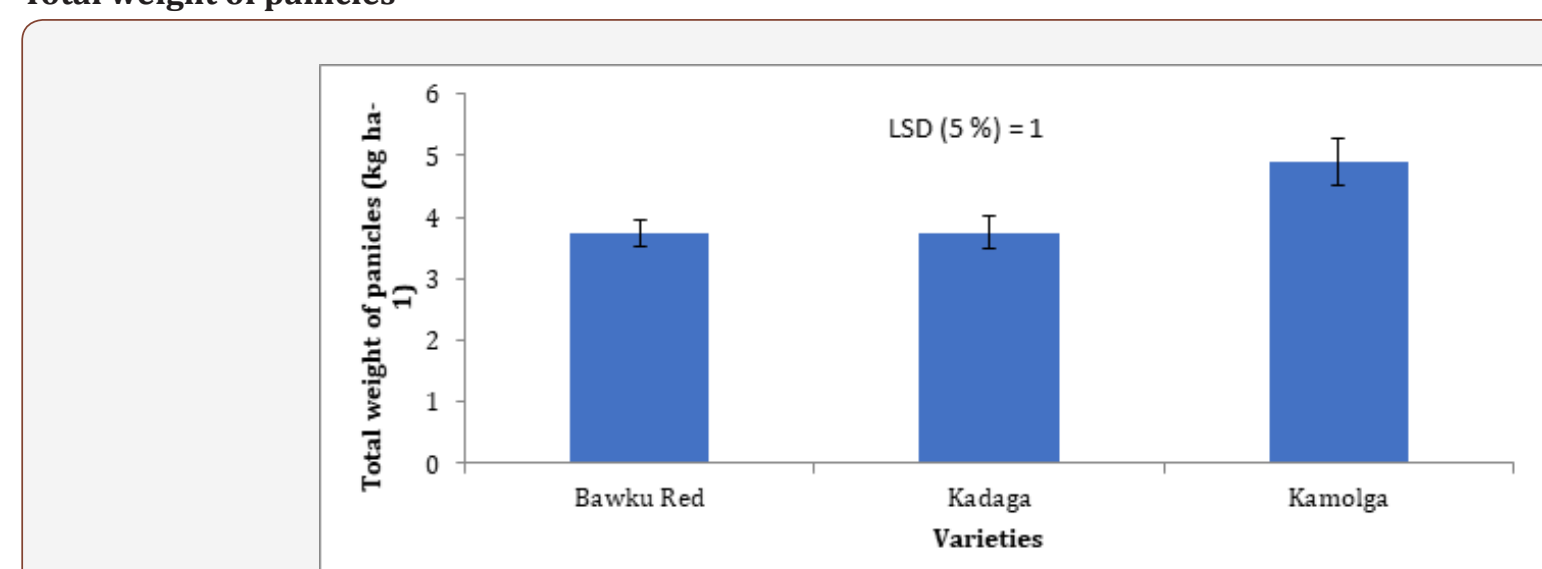

Figure 7: Effect of variety on the total weight of sorghum panicles.

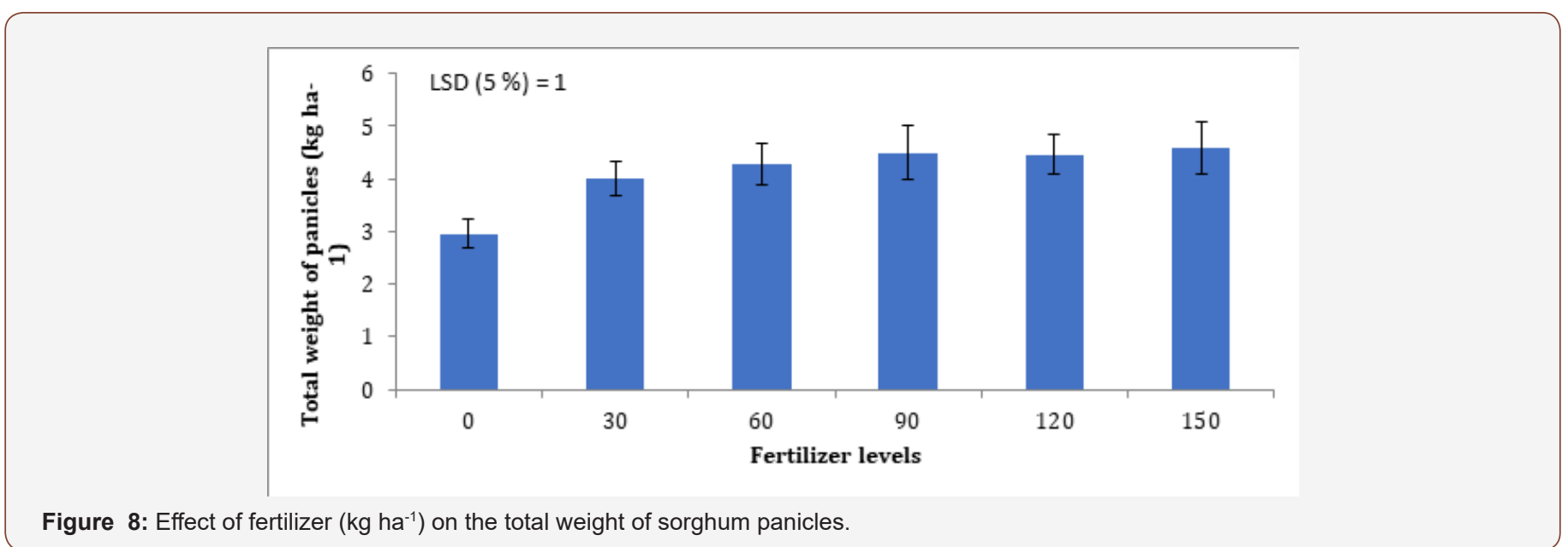


Variety and fertilizer as sole factors significantly affected total weight of panicles $(p<0.05)$. The interaction effect of the two factors on total weight of panicles was, however, not significant $(p>$ 0.05). For variety, Kamolga had the highest mean total weight of panicles (Figure 7). The Kadaga variety had the least mean total weight of panicles though Bawku Red plants also performed simi-

Table 3: Effect of variety and fertilizer rates on the panicle width of sorghum.

\begin{tabular}{|c|c|c|c|c|c|c|}
\hline \multirow{2}{*}{ Variety } & \multicolumn{3}{|c|}{ Panicle Width (cm) } & \multicolumn{3}{|c|}{ Fertilizer Level } \\
\hline & $0 \mathrm{~kg} \mathrm{~N} \mathrm{ha}^{-1}$ & $30 \mathrm{~kg} \mathrm{~N} \mathrm{ha}^{-1}$ & $60 \mathrm{~kg} \mathrm{~N} \mathrm{ha}^{-1}$ & $90 \mathrm{~kg} \mathrm{~N} \mathrm{ha}^{-1}$ & $120 \mathrm{~kg} \mathrm{~N} \mathrm{ha}^{-1}$ & $150 \mathrm{~kg} \mathrm{~N} \mathrm{ha}^{-1}$ \\
\hline Bawku Red & 7.2 & 7.4 & 7.05 & 9.95 & 6.85 & 6.7 \\
\hline Kadaga & 7.7 & 8.35 & 8.45 & 8.1 & 7.95 & 8 \\
\hline Kamolga & 7.65 & 7.4 & 8.35 & 8.15 & 7 & 8.8 \\
\hline LSD (5 \%) & 2.392 & & & & & \\
\hline$\% \mathrm{CV}$ & 21.5 & & & & & \\
\hline
\end{tabular}

\section{Number of branches per panicle}

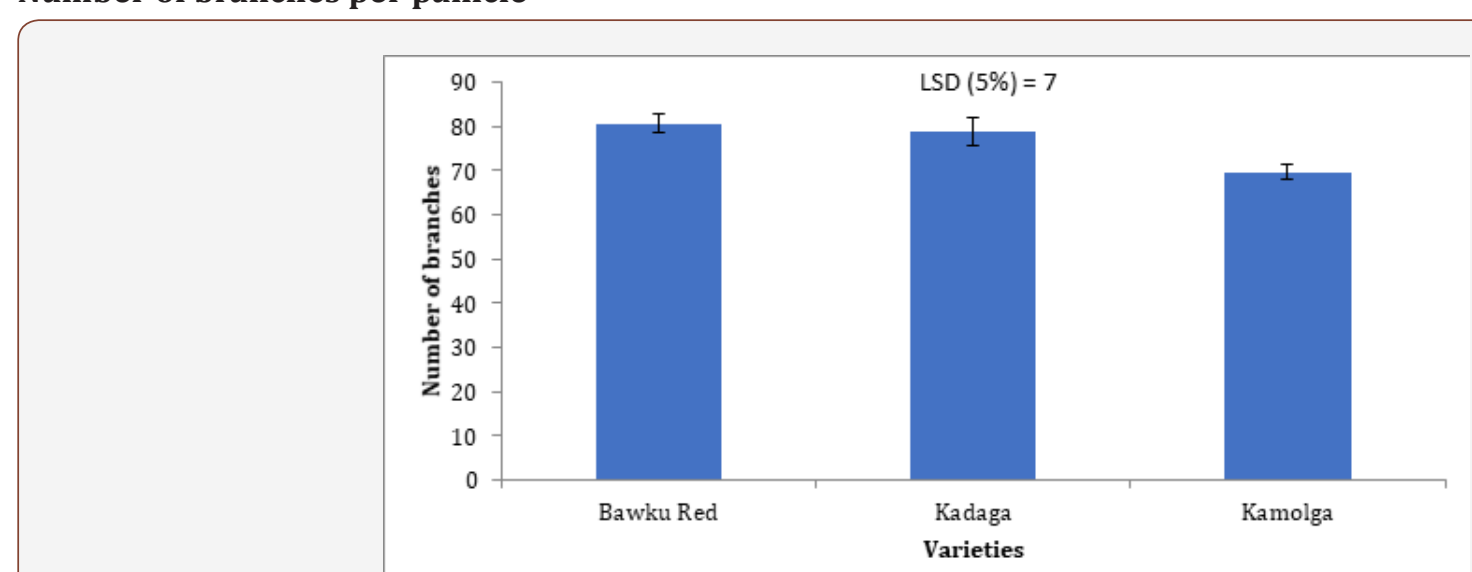

Figure 9: Effect of variety on the number of branches per panicle of sorghum.

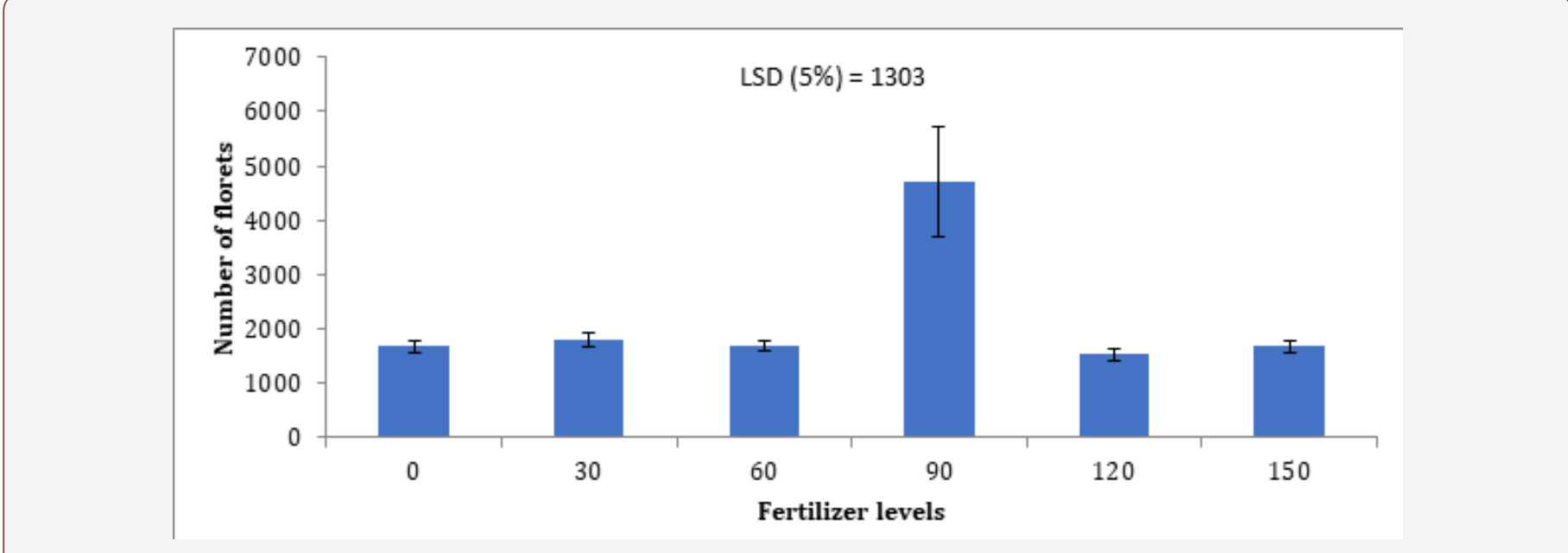

Figure 10: Effect of fertilizer rate $\left(\mathrm{kg} \mathrm{ha}^{-1}\right)$ on the number of sorghum florets per panicle.

The effect of variety on number of branches per panicle was significant $(p<0.05)$. The effects of fertilizer and interaction of the two factors on number of branches per panicle were, however, not significant $(p>0.05)$. It was observed that Bawku Red variety had the highest mean number of branches per panicle though Kadaga plants also performed similarly (Figure 9). The Kamolga variety had the least mean number of branches per panicle. larly. It was also observed that plants fertilized at $150 \mathrm{~kg} \mathrm{~N}^{-1}$ had the highest total weight of panicles (Figure 8). The plants treated with 30,60, 90 and $120 \mathrm{~kg} \mathrm{~N} \mathrm{ha}^{-1}$ had similar performance with those treated with $150 \mathrm{~kg} \mathrm{~N} \mathrm{ha}^{-1}$. The control-treated plants had the least total weight of panicles (Table 3).

\section{Number of florets per panicle}

The effect of fertilizer on number of florets per panicle was significant $(p<0.05)$. The effects of variety and interaction of the two factors on number of florets per panicle were, however, not significant $(p>0.05)$. Plants fertilized with $90 \mathrm{~kg} \mathrm{~N} \mathrm{ha}^{-1}$ had the highest number of florets per panicle (Figure 10). The plants with zero fertilizer application had the least number of florets per pani- 
cle and plants treated with 30,60, and $90 \mathrm{~kg} \mathrm{~N} \mathrm{ha}^{-1}$ as well as those from control plots had similar performances with regards to floret counts.

\section{Number of seeds per panicle}

Fertilizer rate significantly affected the number of seeds per panicle of sorghum $(p<0.05)$. The effects of variety, and interaction of the two factors on number of seeds per panicle were, however, not significant $(p>0.05)$. Plants fertilized with $90 \mathrm{~kg} \mathrm{~N}^{-1}$ had the highest number of seeds per panicle (Figure 11). The zero fertilized treatments had the least number of seeds per panicle and plants treated with 30,60 , and $90 \mathrm{~kg} \mathrm{~N} \mathrm{ha}^{-1}$ as well as those from control plots had similar performance.

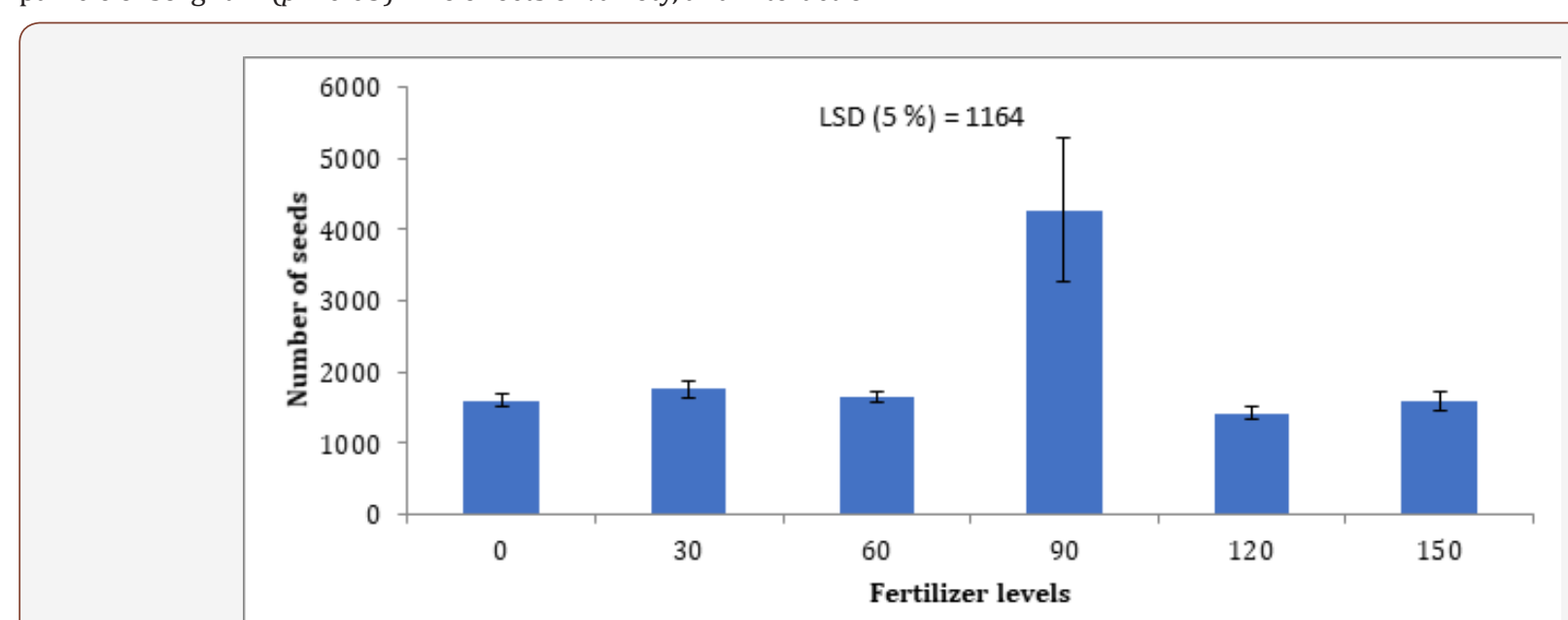

Figure 11: Effect of fertilizer rate $\left(\mathrm{kg} \mathrm{ha}^{-1}\right)$ on the number of sorghum seeds per panicle.

\section{Seed weight per panicle}

Table 4: Effect of variety and fertilizer rate on seed weight per panicle of sorghum.

\begin{tabular}{|c|c|c|c|c|c|c|}
\hline \multirow{2}{*}{ Variety } & \multicolumn{3}{|c|}{ Seed Weight (g) } & \multicolumn{3}{|c|}{ Fertilizer Level } \\
\hline & $0 \mathrm{~kg} \mathrm{~N} \mathrm{ha}^{-1}$ & $30 \mathrm{~kg} \mathrm{~N} \mathrm{ha}^{-1}$ & $60 \mathrm{~kg} \mathrm{~N} \mathrm{ha}^{-1}$ & $90 \mathrm{~kg} \mathrm{~N} \mathrm{ha}^{-1}$ & $120 \mathrm{~kg} \mathrm{~N} \mathrm{ha}^{-1}$ & $150 \mathrm{~kg} \mathrm{~N} \mathrm{ha}^{-1}$ \\
\hline Bawku Red & 56.8 & 63.3 & 60.4 & 57 & 44.5 & 49.4 \\
\hline Kadaga & 47.3 & 83.4 & 63.7 & 63.1 & 49.3 & 49.5 \\
\hline Kamolga & 48.3 & 50.7 & 60.3 & 56.2 & 47.4 & 96.2 \\
\hline LSD (5\%) & 32.06 & & & & & \\
\hline$\% \mathrm{CV}$ & 38.8 & & & & & \\
\hline
\end{tabular}

The sole effects of variety and fertilizer on seed weight per panicle were not significant $(p>0.05)$. The interaction effect of the two factors on seed weight per panicle was however significant ( $p$
$<0.05)$. Highest seed weight per panicle was recorded on Kamolga at fertilizer rate of $150 \mathrm{~kg} / \mathrm{ha}$ (Table 4). Whilst the lowest was recorded with Kadaga at nitrogen rate of zero kg/ha.

\section{0-seed weight per panicle}

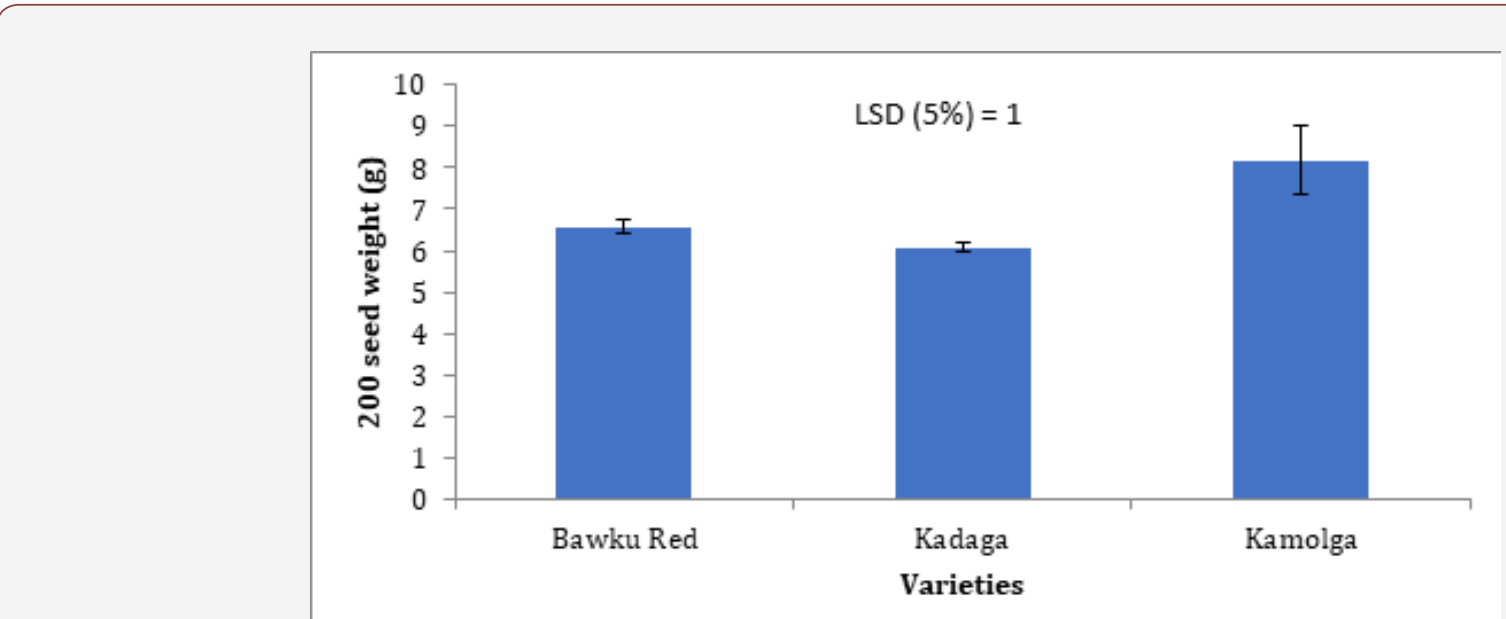

Figure 12: Effect of variety on the 200 seed weight per panicle of sorghum. 
The effect of variety on 200 seed weight per panicle was significant $(p<0.05)$. The effects of fertilizer and interaction of the two factors on 200 seed weight per panicle were, however, not significant $(p>0.05)$. The Kamolga variety had the highest mean 200 seed weight per panicle (Figure 12). The Kadaga plants had the least mean 200 seed weight per panicle though Bawku Red plants also performed similarly.

Table 5: Effect of variety and fertilizer rate on total grain yield $(\mathrm{kg} / \mathrm{ha})$ of sorghum

\begin{tabular}{|c|c|c|c|c|c|c|}
\hline \multirow{2}{*}{ Variety } & \multicolumn{6}{|c|}{ Fertilizer Level } \\
\hline & $0 \mathrm{~kg} \mathrm{~N} \mathrm{ha}^{-1}$ & $30 \mathrm{~kg} \mathrm{~N} \mathrm{ha}^{-1}$ & $60 \mathrm{~kg} \mathrm{~N} \mathrm{ha}^{-1}$ & $90 \mathrm{~kg} \mathrm{~N} \mathrm{ha}^{-1}$ & $120 \mathrm{~kg} \mathrm{~N} \mathrm{ha}^{-1}$ & $150 \mathrm{~kg} \mathrm{~N} \mathrm{ha}^{-1}$ \\
\hline Bawku Red & 354 & 646 & 572 & 418 & 564 & 709 \\
\hline Kadaga & 231 & 825 & 901 & 556 & 820 & 448 \\
\hline Kamolga & 516 & 808 & 984 & 1276 & 892 & 935 \\
\hline LSD (5\%) & 275.9 & & & & & \\
\hline$\% \mathrm{CV}$ & 15.1 & & & & & \\
\hline
\end{tabular}

\section{Discussion}

As in this study, similar variation in sorghum growth and yield parameters with respect to variety and fertilizer rates has earlier been reported by Murleyl, et al., [14]. The best growth performance of sorghum with increasing $\mathrm{N}$ rate is attributed to soil enrichment with higher levels of $\mathrm{N}$-nutrient which provided sufficient $\mathrm{N}$-nutrients and also rendered available, other sorbent and non-available nutrients that are essentially required for various metabolic processes finally resulting in enhanced plant growth [15]. Apart from efficient nutrient utilization, the healthy plants outperformed others in terms of height, leaf number, panicle length and width, number and total weight of panicles (Tables 2 \& 3, Figures 7-12). The observed decreases in growth parameters under low $\mathrm{N} \mathrm{nu}-$ trients are good indicators of yield losses under $\mathrm{N}$ deficiency [16]. This explains the low values of growth parameters observed under the fertilizer rate of $0 \mathrm{~kg} \mathrm{~N} \mathrm{ha}^{-1}$. An increase in the number of leaves is associated with an increase in leaf surface area with increasing population density is associated with effective light interception [17], greater photosynthetic output per unit area and the observed greater dry biomass production [18]. The high number of sorghum seeds observed under the $90 \mathrm{~kg} \mathrm{~N} \mathrm{ha}^{-1}$ fertilized field (Figure 11) is due to the high number of florets per panicle observed under the $90 \mathrm{~kg} \mathrm{ha}^{-1}$ field (Figure 10). Under that growth condition, effective growth of the plant due to efficient resource utilization and facilitated balances of other soil nutrients may have enhanced the growth of sorghum roots thereby assisting in the absorption of water and uptake of essential elements reference show that differences in seed number per panicle might be due to variations in the number of floral initials formed, or to variations in the number which survive to produce grain [19]. The higher the number of flowers, the higher the number of seeds formed. Highest mean weight of 200 seeds observed in the Kamolga variety compared to the lowest observed in the Kadaga variety (Figure 13) is an indication of differences in sorghum seed weight of varieties. As differences in seed weight occurs irrespective of the $\mathrm{N}$ levels, there appears to be a varietal hierarchy in $\mathrm{N}$ translocation from vegetative parts (stem

\section{Total grain yield}

The effects of variety and fertilizer on total grain yield where was affected by the interaction effect of variety and nitrogen fertilizer rate $(p<0.05)$. The Kamolga variety planted at an $\mathrm{N}$ fertilizer rate of $90 \mathrm{~kg} \mathrm{ha}^{-1}$, had the highest yield of $1276 \mathrm{~kg} \mathrm{ha}^{-1}$ (Table 5). The least yield was observed with the Kadaga variety at $\mathrm{N}$ rate of zero $\mathrm{kg} \mathrm{ha}^{-1}$.

or leaf) to grains in sorghum. Kamolga variety at a point must have had internal mechanisms that cause effective translocation of $\mathrm{N}$ compared to the Kadaga variety. Nitrogen translocation to grains has been observed to occur mostly from stem in preference to leaf [20]. These explains the observed higher yield of the Kamolga variety at each $\mathrm{N}$ level compared to the other varieties and also explains the higher yield observed at the $\mathrm{N}$ rate of $90 \mathrm{~kg} \mathrm{ha}^{-1}$.

\section{Conclusion}

There was no interactive effect of variety and fertilizer rate on most growth and yield parameters of sorghum except panicle width and grain yield. Nitrogen fertilizer rate as sole factor affected most growth parameters and most of the yield component parameters. The Bawku red variety had the best performance with respect to aboveground biomass parameters. However, Kamolga variety performed best in terms of the yield parameters, with optimum yield of Kamolga occurring at $\mathrm{N}$ application rate of $90 \mathrm{~kg} \mathrm{ha}^{-1}$. This level of $\mathrm{N}$ application resulted in higher yields due to adequate soil nutrient environment that promoted uptake and enhanced efficient nutrient translocation from leaves and stems into the filling grain. For optimum sorghum production, the Kamolga local variety is therefore recommended for cultivation since it is associated with higher yield under relatively low $\mathrm{N}$ application rate of $90 \mathrm{~kg} \mathrm{ha}^{-1}$.

\section{Acknowledgement}

I deem it necessary to extend my sincere gratitude to Dr. Naab Jesse Bonaventure a senior scientist at West Africa Science Service Center on Climate Change and Adapted Land use (WASCAL), Mr. Aaron Aduna Upper East Regional director of water resource commission (WRC) and to all who immensely contributed in the process of data collection. It is with much pleasure to stretch special thanks to all lecturers in the Department of Agronomy, University for Development Studies.

\section{Conflict of Interest}

No conflict of interest. 


\section{References}

1. Gaboinewe Motlhwa, Mgale Yohana James, Yan Yunxian (2019) Effects of Integrated Support Programme for Arable Agricultural Development (ISPAAD) on the Income of Sorghum Farmers: Evidence from Kweneng District, Botswana. Asian Journal of Agricultural Extension, Economics \& Sociology 36(1): 1-10.

2. Melinda Smale, Amidou Assima, Alpha Kergna, Veronique Thériault, Eva Weltzien (2018) Farm family effects of adopting improved and hybrid sorghum seed in the Sudan Savanna of West Africa. Food policy 7: 162171.

3. Yinping Jiao, Gloria Burow, Nicholas Gladman, Veronica Acosta-Martinez, Chen Junping, et al. (2018) Efficient identification of causal mutations through sequencing of bulked F2 from two allelic bloomless mutants of Sorghum bicolor. Frontiers in plant science 8: 2267.

4. Clara W Mundia, Silvia Secchi, Kofi Akamani, Guanaxina Wang (2019) A Regional Comparison of Factors Affecting Global Sorghum Production. The Case of North America, Asia and Africa's Sahel Sustainability 11(7): 2135.

5. Jianan Wang, Zhenbin Hu, Hari D Upadhyaya, Geoffrev P Morris (2019) Genomic signatures of seed mass adaptation to global precipitation gradients in sorghum Heredity, pp. 1-14.

6. Fantaye Belay, Firew Mekbib Taye Tadesse (2018) Variety x nitrogen fertilizer interaction on striga control, yield and yield related attributes of sorghum [Sorghum bicolor (L.) Moench] under striga infestation Conditions of Abergelle District, Northern Ethiopia. Int J of Life Sciences 7(1): 11-20.

7. Olugbemi O, C Aboyeji, J Olofintoye, E Eifediyi (2018) Growth and Ethanol Yield Responses of Sweet Sorghum [Sorghum bicolor (L.) Moench] Varieties to Nitrogen Fertilizer Rates. Journal of Agricultural SciencesSri Lanka 13(1).

8. Nigus Demelash Melaku, Wondimu Bayu, Feras Ziadat, Stefen Strohmeier, Claudio Zucca, et al. (2018) Effect of nitrogen fertilizer rate and timing on sorghum productivity in Ethiopian highland. Journal of agronomy and Soil Science 64(4): 480-491.

9. Sali, Al-salim Maysoun Mohamed Saleh, Saad Adnan Manhal Albadry (2018) Evaluation Of Performance Of Some Varieties Of Sorghum Bicolor L. Under Different Levels Of Nitrogen Fertilization in Thi-Qar University. Journal of Agricultural Research 7(1).

10. Pradip Roy, Satakshi Basu, Jayeeta Chatterjee, Arunava Goswami, Samarendra Barik (2018) Response of Various Yield of Sweet Sorghum Crop (Sorghum bicolour L. Moench) to Different Levels of Fertilizer in Later- itic Soil of Birbhum, West Bengal. International Journal of Agriculture, Environment and Biotechnology 11(1): 25-32.

11. Isaac larbi, Fabien Hountondii, Thampson Annor, Wilson Agyare, John Mwangi Gathenya (2018) Spatio-Temporal Trend Analysis of Rainfall and Temperature Extremes in the Vea Catchment, Ghana. Academic Open Access publishing 6(4):87.

12. Jan Bliefernicht, S Beyer, S Salack, S Guug, L Hinger, et al. (2018) The WASCAL Hydrometrological Observatory in the Sudan Savanna of Burkina Faso and Ghana. Vadose zone journal/Advancing Critical Zone Science 17(1).

13. MacCarth D S, Adiku S G, Freduah B S, Kamara A Y, Narh S (2018) Evaluating maize yield variability and gaps in two agroecologies in northern Ghana using a crop simulation model. South African Journal of Plant and Soil 35(2): 137-147.

14. Cameron B Murley, Sumit Sharma, Jason G Warren, Daryl B Arnall, William R Raun (2018) Yield response of corn and grain sorghum to row offsets on subsurface drip laterals. Agricultural water management 208: 357-362.

15. Adebola Ajidahun, Erick Sebetha (2019) Effects of cultivars, nitrogen fertilizer rate and plant density on the yield and yield components of sorghum. Research on Crops 20(2): 275-284.

16. Muhammad Aamir Iqbal, Asif Iqbal, Rana Nadeem Abbas (2018) Spatio-temporal reconciliation to lessen losses in yield and quality of forage soybean (Glycine max L.) in soybean-sorghum intercropping systems. Bragantia 77(2) :283-291.

17. Zhixin Zhang, Michael Christensen, Zhibiao Nan, Jeremy PM Whish, Lindsay W Bell, et al. (2019) Plant development and solar radiation interception of four annual forage plants in response to sowing date in a semi-arid environment. Industrial Crops and Products 131: 41-53.

18. Ogbaga CC, Amit K Bajhaiya, SK Gupta (2019) Improvements in biomass production: Learning lessons from the bioenergy plants maize and sorghum. Journal of Environmental Biology 40(3): 400-406.

19. Christian O Dimkpa, Upendra Singh, Prem S Bindraban, Wade H Elmer, Jorge L Gardea Torresdey et al. (2019) Zinc oxide nanoparticles alleviate drought-induced alterations in sorghum performance, nutrient acquisition, and grain fortification. Science of the Total Environment 688: 926934.

20. Reddy P Sanjana (2019) Breeding for Abiotic Stress Resistance in Sorghum. In Breeding Sorghum for Diverse End Uses. Woodhead Publishing Series in Food Science Technology and Nutrition, pp. 325-340. 